\title{
O ativismo digfital de Lorelay Fox: estética e performance de gênero ${ }^{1}$
}

\section{Lorelay Fox's digital activism: aesthetics and gender performance}

Josefina de Fatima Tranquilin Silva

Resumo: Neste artigo, indago o canal do YouTube Para Tudo da drag Lorelay Fox, problematizando seu caráter político e comunicacional, uma vez que as tecnologias estão imbricadas às apropriações politicas juvenis operadas nas cartografias digitais. O objetivo é discutir como a performance e a estética de Lorelay Fox configuram seu ativismo de gênero. A metodologia é a etnografia: a "observação densa" dos vídeos e a entrevista em profundidade aplicada a Danilo Dabague - criador da Lorelay Fox - formatam o trabalho de campo.

Palavras-chave: ativismo digital e politicidades; etnografia; drag Lorelay Fox; estética e performance; juventudes

Abstract: In this article I inquire the YouTube channel "Para Tudo" of the drag Lorelay Fox, questioning its political and communicational character, since the technologies are embedded to youth political appropriations operated in digital cartographies. The aim is to discuss how the performance and aesthetics of Lorelay Fox configure their gender activism. Ethnography is the methodology: the fieldwork is formatted by the "dense observation" of the videos and the in depth interview with Danilo Dabague - the creator of Lorelay Fox.

Keywords: digital activism and political nature; ethnography; drag Lorelay Fox; aesthetics and performance; youths

1 Pesquisa desenvolvida no Programa de Pós-graduação em Comunicação e Práticas do Consumo, sob a supervisão da profa. dra. Rosamaria Luiza de Mello Rocha e financiada pela Fapesp/Capes. Processo no 2014/11551-0. Fundação de Amparo à Pesquisa do Estado de São Paulo (Fapesp). 2 Universidade de Sorocaba (Uniso). Sorocaba, SP, Brasil. Programa de Pós-graduação em Comunicação e Práticas de Consumo ESPM-SP. São Paulo, SP, Brasil. E-mail: tranquilinfina@gmail.com 


\section{Lorelay Fox: referência política para as juventudes LGBTs}

Lorelay Fox, lembranças e reencontro: descubro a existência de Lorelay Fox em 2015 por meio das "rodas de conversas" das juventudes de Sorocaba, cidade do interior paulista. Nesse mesmo ano, a Parada LGBT de Sorocaba passa a ter um novo formato, agora mais político: os organizadores criaram o Nós Diversos, ${ }^{3}$ que, segundo Kadu Nunes, coordenador de mídia da Parada, "é um ciclo de debates presenciais sobre temas LGBTs e feministas realizados no Sesc Sorocaba” e tem como objetivo "debater pautas LGBTs e feministas para, nesse espaço, desconstruir preconceitos e respeitar as diferenças, criando novos nós de afetividade e diversidade". Em um dos encontros em que estive presente, Kadu exibe a agenda e alguns dados referentes ao aumento do público a cada evento. Uma das justificativas para isso é o vídeo gravado por Lorelay Fox em apoio ao Nós Diversos e à Parada. Quando o vídeo é exibido, a plateia, mesmo já tendo conhecimento dele, aplaude entusiasmada. Percebo, então, que Lorelay é mais que uma drag citada nos bate-papos juvenis, é um símbolo político para as juventudes LGBTs, ativistas de gêneros ou não, de Sorocaba.

Para alguém que pesquisa gêneros, juventudes, práticas de consumo, ativismo e redes digitais, é óbvio inquietar-se com essa drag sorocabana que se revolve como símbolo juvenil, principalmente entre os ativistas das causas LGBTs. Vou, então, procurar saber quem é Lorelay Fox. Inauguro uma busca pela sua page no Facebook e lá encontro uma foto do criador de Lorelay - Danilo Dabague. E qual é a minha surpresa? Danilo foi meu aluno há 10 anos, quando Lorelay já existia como performista em shows nas casas noturnas de Sorocaba. Eu sempre soube que Danilo se "vestia" de mulher, mas minhas lembranças passavam por outros meandros: jovem inteligente, sensível e criativo. Entro rapidamente no messenger do Facebook e troco com Danilo mensagens

3 "Nós Diversos" foi idealizado e organizado por: grupo de ativismo Coletivo LGBT; grupo feminista Mandala; Núcleo de Estudos de Gênero e Diversidade Sexual - UFSCar Sorocaba; Parada LGBT de Sorocaba; e Sesc Sorocaba. 
carinhosas, embaladas por muitas saudades, elogios e cumplicidades. Eis um grande encontro.

A partir do Facebook, me deparo com seu canal no YouTube e com seus muitos seguidores - hoje, mais de 10 mil. Desvendo ali, imediatamente, a existência de um ativismo digital de gênero. Animada, pois um objeto/sujeito de estudo maravilhoso acabava de atravessar-me por completo, começo a assistir avidamente a todos os seus vídeos postados em Para Tudo de Lorelay Fox, seu canal, o que me inspira as reflexões e o objetivo deste artigo: ${ }^{4}$ discutir a estética e a performance de Lorelay Fox como possibilidades de negociação de sentidos entre ela e as juventudes que, em seu canal, se fazem visíveis. Interessante perceber que estamos tratando de uma estética de "montagem”, que dá vida a uma personagem feminina - e não uma mulher? - protagonista do ativismo de gêneros existente no canal.

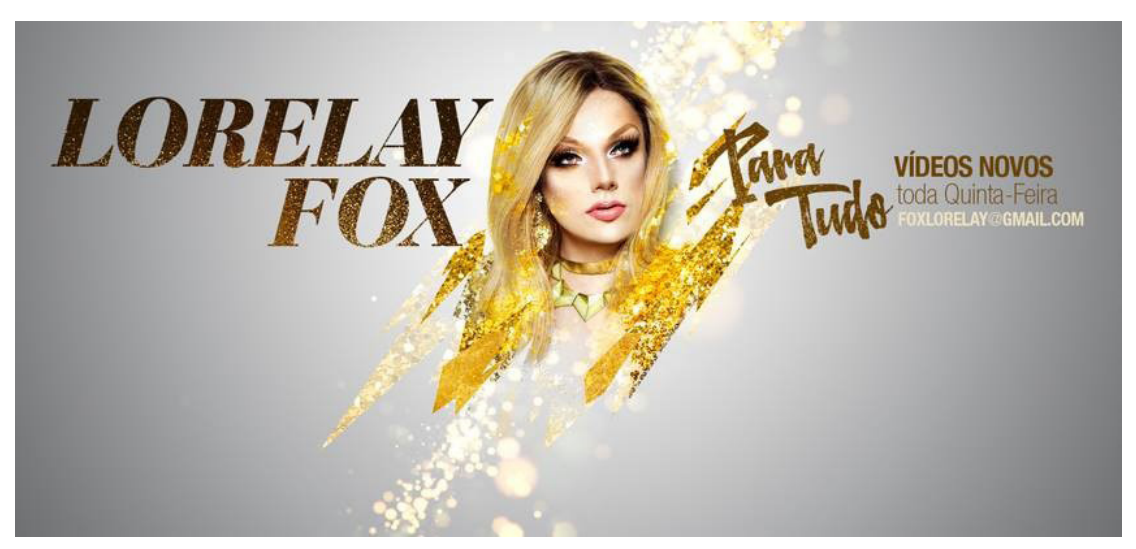

Fonte: YouTube. ${ }^{5}$

Refletir sobre os ativismos juvenis de gêneros na contemporaneidade é entender que as ações políticas das juventudes ocorrem nos territórios

4 Este artigo amplia consideravelmente as discussões presentes em comunicações feitas em dois congressos: VI Congresso da Associação Portuguesa de Antropologia, Coimbra, Portugal; ComuniCon 2016: Congresso Internacional em Comunicação e Consumo, ESPM-SP.

5 Para Tudo de Lorelay Fox. Disponível em: https://www.youtube.com/channel/UC-NW3bCGpuJm6fz-9DyXMig. Acesso em: 12 fev. 2017. 
presenciais e nos ambientes digitais. Di Felice (2003, p. 54), analisando a dimensão da cidadania nos espaços digitais, apregoa que "essa dimensão específica nos leva à necessidade, no interior da análise do net-ativismo, de aprofundar o significado da ação social, buscando entender e pensar a qualidade da ação na rede [...]”. Como nos diz Martín-Barbero (2008, p. 211):

O 'lugar' da cultura na sociedade muda quando a mediação tecnológica deixa de ser meramente instrumental para tornar-se espessa, densificar-se e converter-se em estrutural. A tecnologia remete hoje não apenas a novos aparatos, como também a novos modos de "percepção" e de "linguagem' a novas sensibilidades e escrituras. Radicalizando a experiência de desancoragem produzida pela modernidade, a tecnologia deslocaliza os saberes modificando tanto o estatuto cognitivo quanto o institucional das 'condições do saber e as figuras da razão' (Chartron), o que está conduzindo a uma forte diluição das fronteiras entre razão e imaginação, saber e informação, natureza e artifício, arte e ciência, saber experto e experiência profana (Castells).

As juventudes são as protagonistas nesse processo de mudança cultural, pois ocupam os espaços digitais e tecem ações políticas, demonstrando o quanto as mediações tecnológicas convertem-se em estruturais. Como diz o próprio Martín-Barbero (1998), a tecnologia torna-se "tecnicidade". Nesse contexto, as juventudes são aqui analisadas como "uma prática, cujo momento etário se retrai ou se dilata de acordo com a participação dos indivíduos e os contextos das dimensões social, cultural, política e econômica" (PRATA, 2008, p. 223).

O caminho metodológico foi o da etnografia digital (ou netnografia) ${ }^{6}$ na perspectiva das autoras Amaral, Natal e Viana (2008, p. 35), que, a partir da etnografia dos espaços físicos, constroem a etnografia digital. Para elas, a etnografia digital "leva em conta os processos de sociabilidade e os fenômenos comunicacionais que envolvem representações do homem dentro das comunidades virtuais". Levi-Straus (2008, p. 14), a

6 Segundo as autoras, enquanto a etnografia digital se faz por meio da antropologia, a netnografia está mais próxima da administração e do marketing. No texto, esses termos são usados como sinônimos (AMARAL, NATAL e VIANA, 2008, p. 34). 
etnografia "consiste na observação e análise de grupos humanos considerados em sua particularidade (...) e visando à reconstituição, tão fiel quanto possível, da vida de cada um deles". Assim, confiamos que a etnografia propõe formas de identificar como se configuram os espaços digitais; de cartografar as teias de relações simbólicas e imaginárias; de detectar como essas relações são construídas e, no caso desta pesquisa, de analisar os elementos que compõem o ativismo de Lorelay Fox. Portanto, a técnica da "observação" do canal Para Tudo de Lorelay Fox e a entrevista em profundidade aplicada a Danilo Dabague - criador da Lorelay - compõem o trabalho de campo etnográfico. É importante destacar que os comentários postados pelos sujeitos interlocutores desse canal são percebidos nesta pesquisa como "vocalidades" (ZUMTHOR, 1987), apesar de, neste artigo, não termos feito pesquisa de recepção.

\section{Urbania: experiências de corporeidades e corporalidades intoleráveis}

Quando pesquisamos sobre as redes digitais, gêneros, sexualidades, corpos, ativismos digitais e, especificamente, uma drag queen, ${ }^{7}$ temos como contexto a contemporaneidade, momento sociopolítico-cultural no qual as urbanidades, as práticas de consumo e as linguagens midiáticas são os motores das ações cotidianas, principalmente das juventudes.

Para Martín-Barbero (2008, p. 208), vivemos nas "urbanias”, os "novos modos de estar juntos, [vistos nas] massas, tribos, bandos, gangues, guetos, comunitarismos étnicos, religiosos, de gênero, etc." Para o autor, estão presentes nessas urbanias as "trajetórias e os entrecruzamentos" vistos por meio dos "migrantes, deslocados, exilados, estrangeiros, párias, e também índios, negros, turcos, judeus, mulheres, gays, homossexuais, prostitutas, travestis, vagabundos, lúmpen, etc." que estão inscritos em "palimpsestos" e "hipertextos" observáveis nos "muralismos diversos, 'rockerias' múltiplas, esoterismos, 'santerias', orientalismos, 'rapperias', performances, etc.”. E assim constroem-se

7 Utilizo o termo drag e não crossdresser porque é assim que Lorelay Fox se define. 
as "cidadanias", a partir das "heterogeneidades", "o projeto de "formar a cidade' com memórias locais e utopias universais". Essas cidadanias são "reinvenções", pois "o projeto de 'fazer política' passa pelo movimento que leva da representação ao reconhecimento passando pela participação e a autogestão" e possui "intermediabilidade", "o projeto de 'recriar a cidade' com oralidades indígenas, corporalidades negras, textualidades eruditas e visualidades digitais”. É nesse contexto que os sujeitos acabam por decodificar a pele que habitam: os corpos. "A imagem do corpo é o efeito, o resultado, a construção que se produz por meio da subjetivação das estruturas que antecedem nossa entrada no mundo" (CORTÉS, 2008, p. 125). Nesse sentido, ao analisarmos as corporeidades e as questões dos gêneros, entendemos que existem grandes dificuldades para que os sujeitos criem narrativas que demonstrem a aceitação do eu, do eu em sintonia com o outro e do próprio outro, pois os corpos denunciam as particularidades do eu e as diferenças inaceitáveis do outro: aquele que foge das acessões culturais.

Nessas urbanias, de tantas trajetórias e entrecruzamentos, vale a pena problematizar até que ponto as distintas corporalidades são aceitas; se a regulação e o controle social dos corpos estão ou não em vias de extinção. Perguntamos: deveria ser recorrente a aceitação daquelas corporalidades estampadas nos muros das cidades, deflagradas nas performances e que fogem à regulação e ao controle social de gênero? Deveria, mas ainda não é, pois as urbanias não são homogêneas em toda a geografia de uma metrópole ou das metrópoles. Os espaços metropolitanos são compostos por "cartografias físicas" e "cartografias simbólicas" (SILVA, 2001) diferenciadas, e isso faz com que certas corporalidades, aquelas que chocam, sejam aceitas em determinados lugares e não em outros; sejam grafadas nos muros, aplaudidas nas performances, mas tenham imperdoáveis existências na trama cotidiana. Assim, "os imaginários aparecem [então] como uma estratégia [...] para dar conta dos processos urbanizadores que não são só manifestações de uma cidade, mas também, do mundo [composto por eu, outro e nós] que a urbaniza" (SILVA, 2001, p. 8). 
Butler (2015, p. 231), em diálogo com Young, salienta que tanto o "repúdio" que os indivíduos sentem quanto a "expulsão" que praticam são o alicerce que materializa as "identidades culturalmente hegemônicas em eixos de diferenciações de sexo/raça/sexualidades". Sendo assim, essa aversão leva à expulsão do outro para longe do eu, como se fossem "excrementos", transformando-os em seres "abjetos" e, assim, repudiados. Parece-nos que Gagnon (2006) adverte que o desejo não tem gênero ou, se tem, não é o que mais importa nas relações libidinosas. Diz ele:

Uma complicação mais profunda é que não é óbvio se foram os aspectos de gênero do "quem" que provocaram o desejo nascente, ou mesmo se o desejo está vinculado a algum "quem". O desejo pode concentrar-se em alguém que seja bem-sucedido, em alguém que os outros ou nós desejemos por sua pureza, ou em alguém que possamos dominar, ou por quem possamos ser dominados. O "quem" dessas situações pode ser desprovido de gênero, ou o gênero pode só ter importância na medida em que o sucesso, a pureza e a dominação estejam ligados a ele (GAGNON, 2006, p. 203).

Dessa forma, avaliamos que o "repúdio" e a "expulsão" cometida pelos indivíduos de que nos fala Butler centram-se primeiramente no corpo.

Pesquisas elaboradas pela Agência Brasil nos mostram que, “com 600 mortes em seis anos, Brasil é o [país] que mais mata travestis e transexuais" (CAZARRÉ, 2015). Detalhe: segundo a mesma pesquisa, o índice mais elevado se encontra em São Paulo, uma cidade que é exemplar nas vivências das urbanias. Portanto, os sujeitos experienciam os espaços onde a heterogeneidade está inscrita em "palimpsestos" e "hipertextos" - e essas formas de grafar as diferenças contribuem com a construção de "novas formas de cidadania" (MARTÍN-BARBERO, 2008, p. 208). No entanto, é também nessas desterritorialidades que os indivíduos colocam para fora as demências (MORIN, 1995) que os constituem, expulsando as "abjeções" ao se depararem com os sujeitos-outros. Estes, por terem corporalidades tão diversas, remetem os sujeitos que com elas se confrontam a uma ideia de que ali há um corpo - um gesto, um jeito, 
uma estética, uma representação - que quebra a regulação e o controle social do gênero e, por isso, precisa ser repudiado e expulso.

Leite Junior (2011, p. 559), refletindo sobre a noção de "abjeto" presente nas análises de Butler, informa-nos que a filósofa o utiliza com "parcimônia, mas se pode seguir uma linha constante em suas análises: o ‘abjeto’ é o que, na constituição do sujeito socialmente inteligível, é colocado 'de fora' desse sujeito, tornando-se seu exterior constitutivo". A representação do corpo é mais do que uma simples imagem, ela é um código que nos aproxima ou nos distancia do poder, da ética, do afeto e da moral. Por isso o corpo é corporeidade e corporalidade.

Butler (2015) entende os gêneros como performáticos. Ao se perguntar "qual é a lei interditora que gera a instabilização corporal do gênero, a representação fantasiada e fantasiosa do corpo" (2015, p. 234), a filósofa explica o gênero: quando a cultura produz a disciplinarização dos gêneros, acaba por solidificar uma falsa noção de estabilidade destes, pois, na verdade, os corpos nunca foram e nunca serão estáveis e, por isso, não há necessidade de os sujeitos optarem por ser de um determinado gênero nem de ter essa ou aquela identidade de gênero. Essas opções são necessárias somente a fim de contribuir com a sedimentação da regulação heteronormativa. O gênero é, então, "um meio de decodificar o sentido e de compreender as relações complexas entre diversas formas de interação humana” (SCOTT, [s.d.]). ${ }^{8}$ Assim, podemos dizer, por exemplo, que as orientações sexuais que fogem à regulação normativa "bagunçam" a noção de gênero: os homossexuais e bissexuais desarranjam e desagregam essa "ficção reguladora", profere Butler (2015).

Nesse sentido, Scott (1998, p. 303) elabora críticas fundamentais aos estudos advindos da "história ortodoxa" e das ciências sociais e humanas quando essas áreas de conhecimento, ao efetuarem pesquisas sobre feminismo, homossexualidade, identidade de gênero etc., não conseguem desconstruir o cerne da questão, que é "a estrutura da economia fálica",

8 O artigo utilizado pode ser encontrado em diversos endereços eletrônicos, mas foi originalmente publicado em: http://www.dhnet.org.br/direitos/textos/generodh/gen_categoria.html. Acesso em $1^{\circ}$ mar. 2016. 
e acabam promovendo somente a visualidade de certas questões dentro dessa economia:

Não apenas a homossexualidade define a heterossexualidade especificando seus limites negativos, e apenas a fronteira entre ambas é mutável, mas ambas operam dentro das estruturas da mesma "economia fálica" - uma economia cujos fundamentos não são levados em consideração pelos estudos que procuram apenas tornar a experiência homossexual visível [...]. Teorizado desta forma, homossexualidade e heterossexualidade trabalham de acordo com a mesma economia, suas instituições sociais espelhando uma à outra $[\ldots]$. Na medida em que esse sistema constrói sujeitos de desejo, simultaneamente estabelece-os, e a si mesmos, como dados e fora do tempo, do modo como as coisas funcionam, com o modo que inevitavelmente são (SCOTT, 1998, p. 303-304).

A partir do momento em que muitas pesquisas sobre gênero efetuadas na história - assim como em muitas outras áreas de conhecimento, como a antropologia, a sociologia e também a comunicação - não questionam a estrutura da "economia fálica", elas reforçam a "naturalização" ou "naturalidade" da categoria de gênero e, assim, contribuem para que determinados corpos continuem a ser indesejados, pelo menos nos espaços públicos. Porém, contraditoriamente, a presença vívida desses corpos indesejáveis evidencia a pusilanimidade do modelo de gênero. "O ideal regulador é então denunciado como norma e ficção que se disfarça de lei do desenvolvimento a regular o campo sexual que se propõe descrever" (BUTLER, 2015, p. 234).

Refletindo sobre os corpos não representáveis e o gênero como uma edificação dramática, pusilânime, simbólica, aleatória de sentido e, portanto, performativa, são muitos esses corpos, dentre os quais apartamos aqueles travestidos, principalmente os das drags. Para Butler, "a performance da drag brinca com a distinção entre a anatomia do performista e o gênero que está sendo performado". Isso porque a drag carrega consigo "três dimensões contingentes da corporeidade significante: sexo anatômico, identidade de gênero e performance de gênero" (BUTLER, 2015, p. 237). 
Danilo compreende que Lorelay pode ser vítima de repulsa do outro: "quando eu tô montado geralmente eu estou num meio que me favoreça, né? [...] eu sei que posso ser vítima de ódio das pessoas [...]”. Revela, de forma extrovertida, que Lorelay já sofreu violência quando ainda não era uma youtuber: "fui vítima de algo violento quando eu trabalhava como hostess numa balada... o povo que passava de carro era bem agressivo... jogava ovo... jogava várias coisas na gente... era divertido [...]"; e demonstra que, depois das redes digitais, a realidade é outra: "hoje em dia, não sou mais agredido... deve ser justamente pelo respeito que conquistei com o canal".

Vemos, então, que Danilo, ao dar vida à Lorelay Fox - 10 anos atrás -, assume ser o "outro", o "abjeto", o corpo não representado que sofreu a violência e ainda pode ser vítima de ódio, causado pela "repulsa" e "expulsão" que os sujeitos sentem e fazem desse outro. A partir disso, algumas perguntas se fazem importantes para esta reflexão: se as drags podem ser consideradas esse outro abjeto, como Lorelay consegue ter mais de 10 mil seguidores/interlocutores, inclusive aqueles que não se colocam como LGBTs? Será que o fato de Lorelay ser hoje uma youtuber a transforma em um corpo representável, mesmo que sua performance brinque com a distinção entre a anatomia do performista e o gênero que está sendo performado? Com isso, Lorelay consegue dar visibilidades e "vocalidades" (ZUMTHOR, 1987) a outros corpos não representáveis nessa cultura das visualidades?

Se nossa análise tem como foco o corpo, a corporeidade, a corporalidade, encontramos na estética, na montagem de Lorelay, um dos principais elementos que interrogam as relações entre sexo anatômico, identidade de gênero e performance de gênero (BUTLER, 2015): os corpos representáveis.

Representação feminina normalmente loira, porém se metamorfoseia em ruiva ou morena; maquiagem exuberante; brincos, colares, tiaras, pulseiras e broches compõem sua estética de montagem para o canal. Fora dele, mostra ainda um figurino de cores fortes e vibrantes; meias arrastão; nádegas, peitos e culotes falsos e avolumados. 


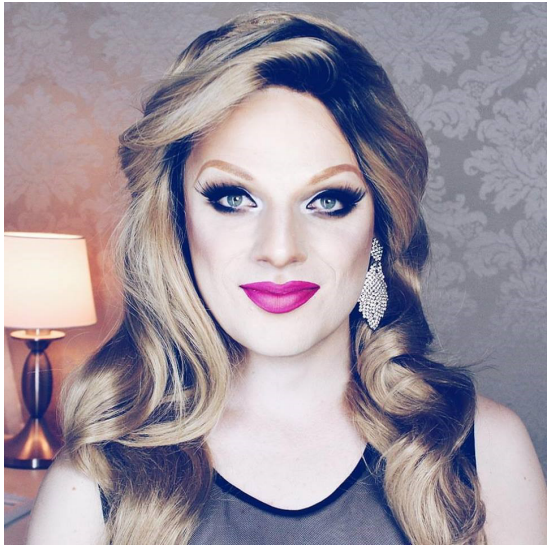

Fonte: Facebook ${ }^{9}$

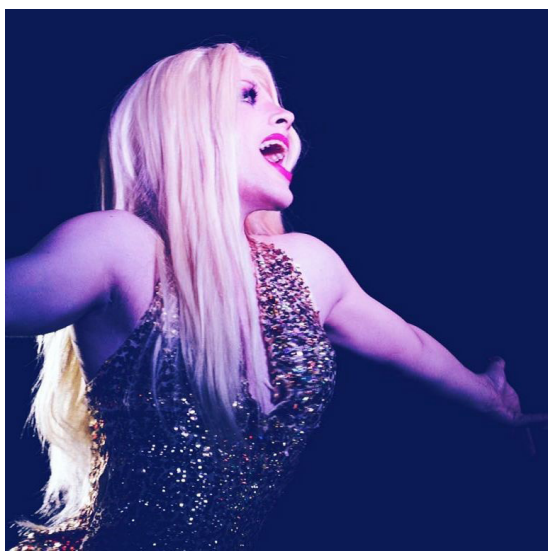

Fonte: Facebook ${ }^{11}$

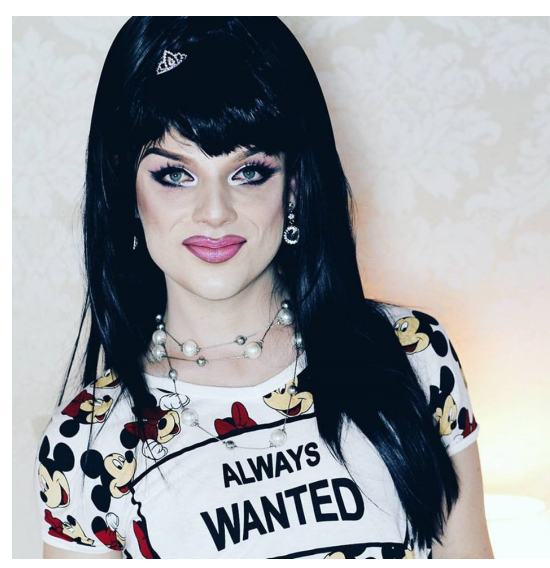

Fonte: Facebook ${ }^{10}$

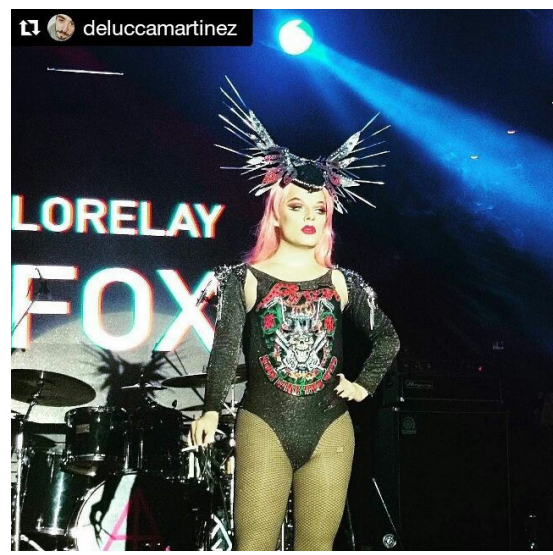

Fonte: Facebook ${ }^{12}$

9 Foto extraída da linha do tempo de Lorelay Fox no Facebook. Disponível em: https:/www.Facebook.com/photo.php?fbid=1760867794128772\&set=pb.100006167057857.-2207520000.1486929370.\&type=3\&theater. Acesso em: 12 fev. 2017.

10 Foto extraída da linha do tempo de Lorelay Fox no Facebook. Disponível em: https://www.Facebook.com/photo.php?fbid=1730294080519477\&set=pb.100006167057857.-2207520000.1486929371.\&type=3\&theater. Acesso em: 12 fev. 2017.

11 Foto extraída da linha do tempo de Lorelay Fox no Facebook. Disponível em: https:/www.Facebook.com/photo.php?fbid=1785221498360068\&set=pb.100006167057857.-2207520000.1486929337.\&type=3\&theater. Acesso em 12 fev. 2017.

12 Foto extraída da linha do tempo de Lorelay Fox no Facebook: Disponível em: https://www.Facebook.com/photo.php?fbid=1710054929210059\&set=pb.100006167057857.-2207520000.1486930083.\&type=3\&theater. Acesso em 12 fev. 2017. 
Olhando para ela - nos territórios físicos ou em seu canal -, vemos uma apropriação e novos usos da estética feminina advindos dos produtos culturais midiáticos, aquela estética criada pelo cinema da década de 1950 e que ainda hoje faz sentido: a mulher fatal, a mulher-objeto, a mulher-sujeito, a virgem, a santa, a sedutora, a vamp, a puta.

Observando alguns comentários, notamos que a paixão de seus interlocutores é construída a partir dessa sua estética midiática pop - pois é assim que ela se oferece - presente nos produtos midiáticos que são citados em seus vídeos, como séries de TV, músicas pop, filmes hollywoodianos, literatura best-seller. Atentemo-nos à estética de Lorelay nos dizeres de seu criador:

Desde o início busquei as referências no mundo pop... nas músicas, nas séries, nos filmes... naquelas coisas que são dos jovens... A Lorelay é moderna, ela é diva, é musa, é drag. Você tinha que ver o meu último show quando cantei "O tempo não para", do Cazuza... foi demais... Aproveitei o momento político e pensei: é a hora de detonar... Fiz o show usando a bandeira do Brasil. Foi lindo... a galera pirou!

Para seus interlocutores, ela é "diva”, "linda", "mara”. Estamos, então, diante de uma estética que provém das visualidades e propõe visibilidades? Concordamos com Rocha (2012) quando diz que "assumindo nosso foco analítico particular, pensamos a cultura a partir das visualidades e a política a partir das visibilidades”. Para Rincón (2006, p. 203), "um olhar fugaz e efêmero à nossa paisagem artificial nos permite constatar que habitamos uma proliferação de imagens, que as imagens têm o dom da ubiquidade e que habitamos uma estranha fascinação pela reprodução visual" (tradução nossa). ${ }^{13}$ Danilo leva para seu corpo masculino uma estética feminina: a estética da montagem. Por conseguinte, há aí marcas da cultura no corpo: essa cultura que é midiática, que cria corpos midiáticos, reconhecíveis, identificáveis. De forma complementar, interdependente e contraditória, as marcas da cultura no corpo de

13 "Una mirada fugaz y efémera a nuestro paisaje artificial nos permite constatar que habitamos una proliferación de imágenes, que las imágenes tienen el don de la ubiquidad y que habitamos una extraña fascinación por la reproducción visual.” 
Lorelay inserem-se em uma performance que caçoa, ri, brinca com as diferenças entre a anatomia masculina de Danilo e o gênero feminino que está sendo performado.

Na década de 1960, Morin (1969, p. 77) já nos dizia que a "cultura de massa é, sem dúvida, a primeira cultura da história mundial a ser plenamente estética”. Isso quer dizer que o cotidiano revela uma força imaginária. As imagens invadem o mundo. "O mundo imaginário não é mais consumido em forma de ritos, cultos, de mitos religiosos, de festas sagradas nas quais os espíritos se encarnam, mas também em forma de espetáculos, de relação estética" (MORIN, 1969, p. 78-79).

Notemos que as referências estéticas de Lorelay pertencem ao universo das juventudes para além do mundo LGBT, ou seja, em sua entrevista e nos vídeos de Lorelay, Danilo nos mostra que há um cotidiano estético - de consumo - compartilhado com as juventudes - interlocutoras de seu canal ou não -, aquelas que são "os herdeiros do século XXI [...] os filhos das imagens eletrônicas e digitais: um universo onde o vídeo é deus, memória e futuro [...]. O vídeo nos tem libertado e nos permite a todos balbuciar resquícios de pensamentos visuais" (RINCÓN, 2006, p. 207, tradução nossa). ${ }^{14}$ Isso significa, como bem nos coloca esse autor, que "a comunicação mediática produz uma cultura que se caracteriza por ser mais de narração e afetividade que de conteúdos e argumentos" (RINCÓN, 2006, p. 18, tradução nossa). ${ }^{15}$ Assistimos, então, a uma performance que, de uma só vez, se insere em um sistema de representação simbólica de participações amplas e de singularidades subjetivas.

Nesse contexto, as juventudes têm extrema facilidade em dar visualidade a seus corpos/imagens e, assim, por meio das narrativas e afetividades, construir políticas de visibilidades nos territórios digitais. Analisando o ativismo gay, Nussbaumer $(2012)^{16}$ salienta que "o

14 "Los herederos del siglo XXI [...] los hijos de las imágenes electrónicas y digitales: un universo donde el vídeo es dios, memoria e futuro [...] El vídeo nos há liberado, ya nos permite a todos balbucear rasguños de pensamientos visual."

15 "La comunicación mediática produce una cultura que se caracteriza por ser más de narraciones y afectividades que de contenidos y argumentos."

16 Disponível em: http://www.portcom.intercom.org.br/pdfs/83579368593431225515764769104 416433682.pdf. Acesso em: 7 maio 2016. 
ciberespaço [...] emerge como um lugar de potencialização da multiplicidade que a cultura gay pode englobar". Nesse sentido, concordamos com Reguillo Cruz (2000, p. 18) que apregoa: "as indústrias culturais [a cultura midiática] têm aberto e desregularizado o espaço para a inclusão da diversidade estética e ética juvenil” (tradução nossa). ${ }^{17}$

\section{Políticas de visibilidades e ativismo digital de gênero: corpos representáveis?}

Um corpo "montado" por si só já quebra as convenções culturais dos corpos representáveis. O corpo montado de Lorelay Fox, visibilizado no canal - e visualizado em outras redes digitais como Facebook, Instagram etc. -, já nos informa que Lorelay participa de outras formas menos tradicionais do "fazer político": as políticas de visibilidades, as "politicidades" (ROCHA e TRANQUILIN-SILVA, 2016, p. 38) comuns entre as juventudes nas contemporaneidades e urbanias. Como nos coloca Aguilera Ruiz (2014, p. 37, tradução nossa): ${ }^{18}$

Expressar, manifestar, visibilizar. Noções que remetem à forma em que aparece diante de nós um grupo de jovens fazendo algo: os vemos, estão ali, se fazem presentes, se visibilizam através de um conjunto de linguagens e estratégias que remetem tanto às características culturais que apresentam as grupalidades juvenis quanto a forma e conteúdo com que a sociedade vai construindo e constituindo os distintos grupos sociais que nela convivem.

Esse conjunto de linguagens e estratégias está claramente colocado nas playlists do canal de Lorelay. Quando eu contei ao Danilo que não selecionei uma playlist específica para analisar o ativismo de Lorelay, já que enxergava ações ativistas no conjunto de seus vídeos, ele

17 "Las industrias culturales han abierto y desregularizado el espacio para la inclusión de la diversidad estética y ética juvenil."

18 "Expresar, manifestar, visibilizar. Nociones que remiten a la forma en que aparecen frente a nosotros un grupo de jóvenes haciendo algo: los vemos, están allí, se hacen presentes, se visibilizan a través de un conjunto de lenguajes y estrategias que remiten tanto a las características culturales que presentan las grupalidades juveniles como a la formas y contenidos con que la sociedad va construyendo y constituyendo a los distintos grupos sociales que en ella conviven." 
me perguntou: "mas mesmo nos vídeos de maquiagem? Quando ensino como faz?”. Ao explicar que a estética da drag está diretamente relacionada a um corpo específico que se montará e que o fato de Lorelay demonstrar os passos de como se maquiar já a coloca como uma ativista - "como sendo parte de um movimento histórico em curso" (Angela Davis), ${ }^{19}$ aquele que luta pela quebra do poder heteronormativo que sustenta o binômio homem e mulher -, Danilo pensa e responde: "pensando por esse lado, acho que sim... porque muita gente vem me perguntar nos vídeos de maquiagem: ah, eu sou mulher, posso me montar? Aí eu falo: vai lá, se divirta, maquiagem não é pra um ou pra outro, é pra todo mundo...”. Isso já demonstra o quanto Lorelay quebra os estereótipos de gênero por meio desses seus vídeos. Continua Danilo: "acho que, pensando assim, talvez eu seja ativista o tempo todo, mas não é uma coisa intencional, não, deve ser uma coisa fluida, que acontece sem eu planejar. Acho que está interno em mim, né?". Tanto é assim, e sua

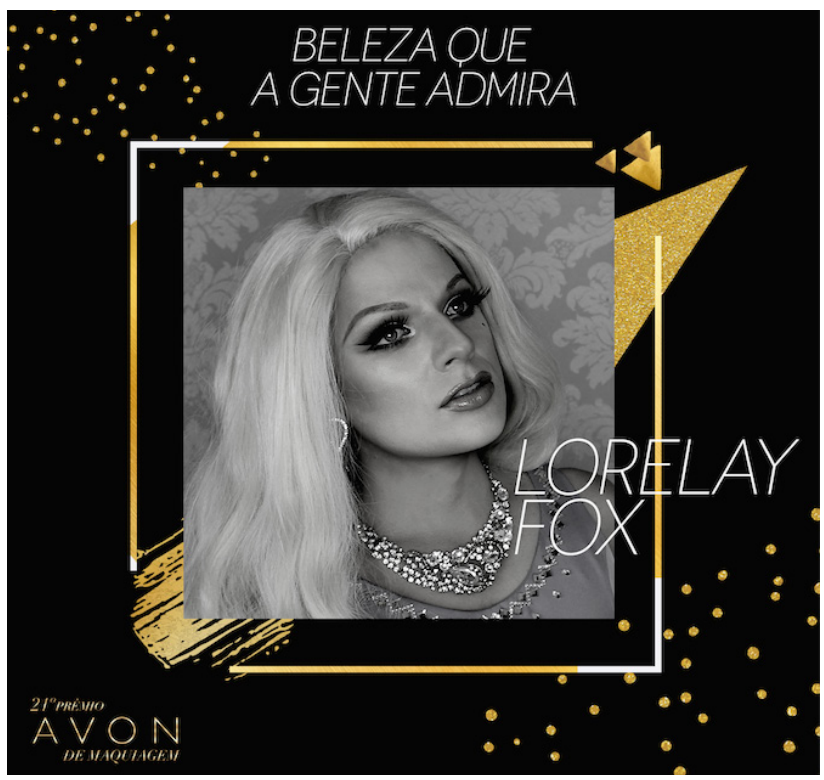

estética se mistura às práticas de consumo, que a Avon, famosa marca de

19 Disponível em: https://www.Facebook.com/SSEXBBOXDoc/?fref=ts. Acesso em: 16 fev. 2016. 
cosméticos, por meio de uma campanha a favor da diversidade, publica em sua page uma homenagem a Lorelay Fox: ${ }^{20}$

Fonte: Facebook

Rainha nos palcos e no discurso, Lorelay Fox é drag queen e uma figura importante no debate de diversos assuntos acerca do universo LGBTQI. Usando sua voz, talento e canal para esclarecer e dar muitos closes certíssimos, utiliza da maquiagem como ferramenta de sua arte e reforço da sua mensagem linda de empoderamento. Não é apenas uma beleza que a gente admira, mas uma beleza que lacra, ensina e desbanca todos os preconceitos.

Lorelay/Danilo, agora entendendo o quanto de politicidades carregam seus vídeos sobre maquiagem e a própria maquiagem que utiliza para se transformar em uma mulher, diz: "a maquiagem [...] é a minha arte, é onde transbordo o meu imaginário [...]. A expressão das minhas contestações políticas, das angústias com o preconceito e dos meus delírios de glamour e beleza”, e finaliza falando do gênero: "maquiagem está além de gêneros e rótulos".

Para Danilo, Lorelay é mesmo uma grande militante na playlist "Reflexões”: “os vídeos de 'Reflexões’ têm um roteiro muito bem feito, quase fala por fala [...]. Eu pesquiso muito”. É notável que, para além do título "Reflexões", Danilo, publicitário de formação, faz pesquisa sobre os assuntos que discutirá e tem um processo "profissional" de criação. Esses elementos já nos mostram o objetivo de transformar a drag Lorelay - que antes existia somente em shows - em uma youtuber ativista das causas de gênero. Danilo continua sua fala sobre "Reflexões", agora em relação ao preconceito que existe mesmo dentro do movimento LGBT: "dentro do movimento gay tem muito preconceito com os gays afeminados [...], acho que o vídeo dos Gays Afeminados fez muito sucesso por causa disso"; faz crítica à ciência quando coloca que "muitas coisas de preconceitos com os gays não têm literatura"; e termina: "eu tenho certeza

20 Como fiquei sabendo dessa campanha pelo Facebook da Lorelay, recolhi as informações em sua page: https://www.Facebook.com/avonbr/photos/p.10154266085436195/10154266085436195/ ?type $=3 \&$ theater. Acesso em: 30 dez. 2016. 
que ajudo os LGBTs a se assumirem. Eles dizem isso. Nessa playlist me considero um verdadeiro ativista de gênero... acho que sou até pelas mulheres e não somente pelos LGBTs.... Você não acha, Fina?”. Partindo do pressuposto de que os corpos são instáveis em relação aos gêneros, as identidades de gênero são movediças, a cultura solidifica a regulação heteronormativa e, por isso, a categoria gênero é performativa, podemos dizer que Lorelay Fox é uma feminista "pós-gênero", aquela que, como ativista de gênero, toma

[...] como políticos os próprios termos em que as identidades são constituídas, o que nos levaria a pensar além da categoria gênero como social, mas entender o poder sobre a materialidade dos corpos como aquilo que constrange a diferença sexual como binária, que não se resolveria na tentativa de construção de novas identidades sexuais e de gênero que possam ir além do par masculino/feminino (RODRIGUES e HEILBORN, 2013, p. 7).

Assim, Lorelay se visibiliza por meio de um conjunto de linguagens e estratégias culturais que definem os pertencimentos juvenis.

Danilo, falando sobre "o poder" de Lorelay, deixa bem claro como sua estética é um elemento de negociação de sentidos entre ela e seus interlocutores: "Lorelay tem o poder que toda arte tem [...], de mexer com o sentimento das pessoas [...]. A partir do momento que a drag é arte, ela sempre causa uma comoção, né?”. Sim, isso é dar visibilidade ao eu e ao outro. "Acho que esse foi o primeiro passo desse sucesso nas redes sociais: ser uma drag, uma forma artística falando, e não ser o Danilo, primeira pessoa falando, entendeu? [...] O Danilo falando não seria tão ouvido, com certeza!". É o corpo de uma jovem drag negociando sentidos, sentimentos e afetos. Sendo assim, a estética de Lorelay, sua performance e "vocalidade" produzem e socializam "as tendências de gosto e de sentimentos" (RINCÓN, 2006, p. 203, tradução nossa). ${ }^{21}$

Assim sendo, Lorelay, aquela drag que zomba da identidade de gênero e possui um corpo não representável no cotidiano, quando está nos

21 "Las tendencias estéticas e los modos del gusto y de sentir." 
espaços digitais e nos lugares de presencialidade - eventos e shows -, torna-se um corpo representável, ao menos em determinados espaços, olhares e escutas. Obviamente, essa conquista não elimina os conflitos entre o "eu" e o "outro" baseados no "repúdio" e na "expulsão", porém Lorelay constrói negociações e agenciamentos com a estrutura do poder. Nesse sentido, temos certeza de que os territórios digitais "desempenham [...] novas formas de sociabilidade, de identidade e de comportamento político e social” (SILVEIRA, BRAGA e PENTEADO, 2012, p. 5). Então, podemos dizer que, ao mesmo tempo, a performance e a estética de Lorelay são perspectivas de construção de subjetividades, símbolo de comunicação e politicidades juvenis.

\section{Referências}

AGUILERA, R. O. Generaciones: movimientos juveniles, políticas de la identidad y disputas por la visibilidad en el Chile neoliberal. Buenos Aires: Clacso, 2014. Disponível em: http://biblioteca.clacso.edu.ar/clacso/becas/20141028030628/generaciones.pdf. Acesso em: mar. 2016.

ALCÂNTARA, L. M.; BRITO D'ANDRÉA, C. F. Redes de movimentos sociais e intervenção na esfera pública interconectada: um estudo da campanha pelo limite da terra na internet. In: SILVEIRA, S.; BRAGA, S.; PENTEADO, V. (Orgs.). Cultura, política e ativismo nas redes digitais. São Paulo: Fundação Perseu Abramo, 2014. p. 103-122.

BUTLER, J. Problemas de gênero: feminismo e subversão da identidade. Rio de Janeiro: Civilização Brasileira, 2015.

CAZARRÉ, M. Com 600 mortes em seis anos, Brasil é o que mais mata travestis e transexuais. EBC Agência Brasil, 13 nov. 2015. Disponível em: http://agenciabrasil.ebc. com.br/direitos-humanos/noticia/2015-11/com-600-mortes-em-seis-anos-brasil-e-o-que-mais-mata-travestis-e. Acesso em: ago. 2016.

COGO, D.; BRIGNOL, L. D. Redes sociais e os estudos de recepção na internet. MATRIZES, ANO 4, N. 2, P. 15-21, JAN.-JUN. 2011. DISPONÍVEL EM: HTTP://WWW. MATRIZES.USP.BR/INDEX.PHP/MATRIZES/ARTICLE/NIEW/75. ACESSO EM: ABR. 2016.

CORTÉS, J. M. G. POLÍTICAS DO ESPAÇO: ARQUITETURA, GÊNERO E CONTROLE SOCIAL. SÃO PAULO: SENAC, 2008. 
DI FELICE, M. SER REDES: O FORMISMO DIGITAL DOS MOVIMENTOS NET-ATIVISTAS. MATRIZES, ANO 7, N. 2, P. 49-71, JUL.-DEZ. 2013. DISPONÍVEL EM: HTTP://WWW.REVISTAS.USP.BR/MATRIZES/ARTICLE/ VIEWFILE/69406/71974. ACESSO EM: ABR. 2016.

FONSECA, L. M. CIBERATIVISMO NA AMAZÔNIA: OS DESAFIOS DA MILITÂNCIA DIGITAL NA FLORESTA. IN: SILVEIRA, S.; BRAGA, S.; PENTEADO, V. (ORGS.). CULTURA, POLÍTICA E ATIVISMO NAS REDES DIGITAIS. SÃO PAULO: FUNDAÇÃO PERSEU ABRAMO, 2014. P. 51-77.

GAGNON, J. H. UMA INTERPRETAÇÃO DO DESEJO. PORTO ALEGRE: GARAMOND, 2006.

LEITE JUNIOR, J. Transitar para onde? Monstruosidade, (des)patologização, (in)segurança social e identidades transgêneras. Estudos Feministas, 20(2), p. 559-568, maio-ago. 2012. Disponível em: http://www.scielo.br/pdf/ref/v20n2/v20n2al6.pdf. Acesso em: abr. 2016.

LEMOS, A. Prefácio. In: AMARAL, A.; RECUERO, R.; MONTARDO, S. Blogs.com. Estudos sobre blogs e comunicação. São Paulo: Momento Editorial, 2009. p. 7-20.

LORELAY FOX. Perfil Facebook. Disponível em: https://www.facebook.com/ lorelayfoxx?fref=ts. Acesso em: dez. 2016.

MARTÍN-BARBERO, J. Arte/comunicação/tecnicidade no final do século. Margem, Educ/Fapesp, n. 8, p. 6-20, dez. 1998a. abr. 2008.

As novas sensibilidades: entre urbanias e cidadanias. Matrizes, n. 2, p. 207-215,

Jóvenes: des-orden cultural y palimpsestos de identidad. In: CUBIDES, H. ET AL. Viviendo a toda. Bogotá: Univesidad Central; Siglo del'hombre, 1998b.

MARTÍN-BARBERO, J. Ofício de Cartógrafo: travessias latino-americanas da comunicação na cultura. São Paulo: Loyola, 2004.

MORIN, E. Cultura de massas no século XX: espírito do tempo. São Paulo: Forense, 1969.

O paradigma perdido: a natureza humana. Lisboa: Europa-América, 1995.

NÓS DIVERSOS. Página do Facebook. Disponível em: https://www.facebook.com/nosdiversos. Acesso em: abr. 2016.

NUSSBAUMER, G. M. Cultura e identidade gay: a diferença do múltiplo. In: INTERCOM -Congresso Brasileiro de Ciências da Comunicação, XXIV, 2001, Campo Grande. Anais... Campo Grande: Uniderp; UCDB; UFMS, 2001. p. 70-85. Disponível em: http://www.intercom.org.br/papers/nacionais/2001/papers/NP13NUSSBAUMER. PDF. Acesso em: maio 2016.

OLIVEIRA, R. O trabalho do antropólogo. São Paulo: Unesp, 2000.

PARA TUDO DE LORELAY FOX. Canal do YouTube. Disponível em: https://www. youtube.com/channel/UC-NW3bCGpuJm6fz-9DyXMjg. Acesso em: jun. 2015.

PARADA LGBT DE SOROCABA. Página do Facebook. Disponível em: https://www. Facebook.com/paradaLGBTSorocaba/?fref=ts. Acesso em: mar. 2016. 
PRATA, P. Dilatada, reconfigurada, contemporânea: juventude e pirataria como exercício de cidadania cultural. Contemporânea, edição especial, v. 16, ano 3, p. 222-243, 2008.

REGUILLO CRUZ, R. Emergencia de culturas juveniles. Estrategias del desencanto. Buenos Aires: Grupo Editorial Norma, 2000.

RINCÓN, O. Narrativas mediáticas: o como se cuenta la sociedade del entretenimento. Barcelona: Gediza, 2006.

ROCHA, R. L. M. Políticas de visibilidade, juventude e culturas do consumo: um caso (de imagem) nacional. In: CONGRESSO LUSOCOM, 8, 2012, Lisboa. Anais... Lisboa: Agacom, 2012. Disponível em: http://conferencias.ulusofona.pt/index.php/ lusocom/8lusocom09/paper/viewFile/95/73. Acesso em: 30 mar. 2016.

ROCHA, R. M.; TRANQUILIN-SILVA, J. F. Alteridade de gênero e deslocamentos de sentido como práticas feministas em rede: observações sobre a página "Moça, você é machista”. Contracampo, v. 35, n. 2, p. 33-51, ago.-nov. 2016. Disponível em: http:// www.contracampo.uff.br/index.php/revista/article/view/934/pdf. Acesso em: jan. 2017. RODRIGUES, C.; HEILBORN, M. L. Gênero e pós-gênero: um debate político. In: SEMINÁRIO INTERNACIONAL FAZENDO GÊNERO, 10, 2013, Florianópolis. Anais... Florianópolis: UFSC, 2013. p. 55-70. Disponível em: http://www.fazendogenero.ufsc.br/10/resources/anais/20/1384187904_ARQUIVO_carlarodrigues.pdf. Acesso em: set. 2016.

SCOTT, J. W. A invisibilidade da experiência. Revista Projeto História, São Paulo, 16 fev. 1998.

Gênero: uma categoria útil para análise histórica. [s.d.]. Disponível em: http:// www.dhnet.org.br/direitos/textos/generodh/gen_categoria.html. Acesso em: mar. 2016. SILVA, A. Imaginários urbanos. São Paulo: Perspectiva, 2001.

SILVEIRA, S. A.; BRAGA, S.; PENTEADO, C. Cultura, politica e ativismo nas redes digitais. São Paulo: Fundação Perseu Abramo, 2014.

STRAUS-LÉVI. C. Antropologia Cultural. São Paulo: Cosacnaify, 2008.

TRANQUILIN-SILVA, J. F. Como os jovens se relacionam com o erotismo? Narratividades eróticas nos ambientes digitais. In: COMUNICON - Congresso Internacional em Comunicação e Consumo, 2014, São Paulo. Anais... São Paulo: PPGCOM/ESPM, 2014. p. 1-15. Disponível em: http://www.espm.br/download/Anais_Comunicon_2014/ gts/gt_cinco/GT05_TRANQUILIN.pdf. Acesso em: 12 fev. 2017.

TRANQUILIN-SILVA, J. F. Sou santa, sou puta, sou filha da luta. In: COMUNICON - Congresso Internacional em Comunicação e Consumo, 2015, São Paulo. Anais... São Paulo: PPGCOM/ESPM, 2015. p. 1-15. Disponível em: http://anais-comunicon2015. espm.br/GTs/GT5/22_GT5_TRANQUILIN-SILVA_.pdf>. Acesso em: nov. 2016.

ZUMTHOR, P. A letra e a voz: a "literatura" medieval. São Paulo: Companhia das Letras, 1987. 
46 O ATIVISMo Digital DE LORELAY FOX: ESTÉTICA E PERFORMANCE DE GÊNERO

\section{Sobre a autora}

Doutora em Ciências Sociais pela Pontifícia Universidade Católica de São Paulo. Pós-doutorado em Comunicação e Práticas do Consumo pelo Programa de Pós-Graduação em Comunicação e Práticas de Consumo pela Escola Superior de Propaganda e Marketing. Professora da faculdade de Jornalismo, Design e Publicidade e Propaganda da UNISO.

Data de submissão: 05/01/2017

Data de aceite: 22/01/2017 